print several times, but some others are wholly new. The longest of the latter group deals with the Socialist party splits resulting from the Comintern challenge. A composite index is appended.

\title{
OTHER BOOKS
}

KRUZE, E. E. Uslovija truda i byta rabočego klassa Rossii v 1900-1914 gg. Pod red. T. M. Kitaninoj. "Nauka”, Leningradskoe otdelenie, Leningrad 1981. $143 \mathrm{pp}$.

Sovetskaja istoriografija Velikoj Oktjabr'skoj socialističeskoj revoljucii. Izdatel'stvo "Nauka", Moskva 1981.293 pp.

UŠaKov, A. V. Bor'ba za edinstvo rabočego klassa Rossii (Dejatel'nost' V. I. Lenina i bol'ševikov po spločeniju proletariata). “Mysl”,'Moskva 1981. 207 pp.

\section{NOTES ON CONTRIBUTORS}

Maria Hunink is research officer in the Internationaal Instituut voor Sociale Geschiedenis.

Elizabeth Roberts is Honorary Research Fellow in the Centre for North-West Regional Studies, University of Lancaster, Lancaster.

Hillel Levine is Professor of Religion, Boston University, Boston.

Walter Schmidt is Director of the Institute for the History of the German Workers' Movement, Akademie für Gesellschaftswissenschaften beim ZK der SED, Berlin. 